\title{
Christen en oorlog
}

Lt A. Boshoff*

In the light of progressive religious pacifism the author discusses the resemblance between religion and military service. In a historical context she determines an evolusionary parallel in religion and war. In this article a brief review of the military past of South Africa mentions the religious nurture of military personnel on South African soil.

Tans woed oorloë in verskillende wêrelddele, o.a. in Libanon, lerland, Iran en Irak terwyl revolusionêre oorloë op haas elke vasteland gevoer word. Saam met hierdie verskynsel ervaar die wêreld egter ook 'n toenemende mate van pasifisme in die Vrye Wêreld en veral die VSA en Wes-Europa. 'n Belangrike dryfveer vir pasifisme is godsdienstige oortuiginge. Ondanks hierdie godsdienstige pasifisme, toon die geskiedenis onteenseglik dat krygsdiens en godsdiens onlosmaaklik aan mekaar verbonde is.

In hierdie artikel word die verband tussen hierdie begrippe in 'n historiese konteks beskou m.b.t. die algemene evolusie van godsdiens naas oorlog. Die rol van godsdiens in die krygsverlede van Suid-Afrika word ook in oënskou geneem. Verskeie tydperke en gebeurtenisse word behandel: die Ou en Nuwe Testamentiese tyd, Kruistogte en Riddertydperk en die Suid-Afrikaanse tydvak. Persone soos Konstantyn die Grote, Ambrosius, Zwingli, Luther, Calvyn en Bullinger geniet aandag. Die geestelike versorging van militêre personeel op Suid-Afrikaanse bodem word ook bespreek.

\section{Historiese Oorsig}

\section{Die Ou Testament}

In die Ou Testament is daar vele beskrywings van oorloë. Merkwaardig is die feit dat hierdie oorloë in opdrag van God gevoer is. ${ }^{1}$ Israel is die uitverkore volk van God kragtens die verbond wat God met Sy volk gesluit het. Volgens hierdie verbond staan Israel as die volk van God aan die een kant terwyl die heidene teenoor hulle staan. Die uitdelging van die heidene het 'n simboliese betekenis gehad: so is die lot van God se vyande. ${ }^{2}$ Hierdie oorloë is beskou as heilige oorloë. Ou Testamentiese oorloë het 'n unieke karakter gehad omdat dit in opdrag van God gevoer is en kan nooit weer herhaal word nie. Moderne oorloë kan daarom nie in dieselfde lig gesien word nie; moderne oorloë kan nie so regverdig word nie. ${ }^{3}$

Die Ou Testament maak egter wel melding van oorloë uit selfverdediging. ${ }^{4}$ Oorloë gevoer met die doel om te straf word dus in die Ou Testament goedgekeur. ${ }^{5}$ Interessant genoeg keur Paulus in sy sendbrief aan die Hebreërs, nie Abraham se militêre bedrywighede af nie. ${ }^{6}$

\section{Die Nuwe Testament}

In die Nuwe Testamentiese tyd is godsdiens en oorlogvoering nie meer met mekaar vereenselwig nie. Die volk Israel het eskatologies geword, met die naam Israel, word nou bedoel, alle gelowiges wat tot die Christelike godsdiens bekeer is. Die Jode het iemand verwag om hulle te verlos van die vreemde heidense staat wat heerskappy gevoer het oor die Beloofde Land. Die soldate wat wel in die Beloofde Land was, het die Keiser as veroweraar verteenwoordig vanweë die feit dat hulle die eed van getrouheid aan die Keiser afgelê het. ${ }^{7}$

Nêrens in die Nuwe Testament word daar vyandigheid jeens die soldaat aangetref nie. Johannes die Doper het nie die soldate wat hom geraadpleeg het, weggewys of verwag dat hulle moes bedank nie, maar hulle aangeraai om met hulle soldy tevrede te wees en niemand geweld aan te doen nie. ${ }^{8}$ Ook Christus het meermale met soldate in aanraking gekom. Hy maak die hoofman oor honderd se dienskneg gesond. ${ }^{9}$ Met sy gevangeneming, verhoor en kruisiging, was $\mathrm{Hy}$ in aanraking met soldate. ${ }^{10}$ Nie een keer het hy die amp van soldaat afgewys nie. By die Kruis tree Hy ook vir die soldate, by God die Vader in, as hy vir hulle voorbidding doen. ${ }^{11}$ Christus is die Staat nie vyandig gesind nie en wys die Fariseërs daarop dat die Keiser op sy belasting geregtig is. ${ }^{12}$ Hy maak in sy gelykenisse van militêre metafore gebruik. ${ }^{13}$ Hoewel Christus nie afwysend teenoor militêre diensplig staan nie, spreek Hy hom uit teen gebruik van geweld, deur sy volgelinge. ${ }^{14}$ Teenoor die Joodse opvatting van 'n oog vir 'n oog en 'n tand vir 'n tand, sê Christus dat ook die ander wang gedraai moet word. Dit word weerspieël in die opdrag van Petrus om die swaard in die skede terug te plaas, want hy wat die swaard opneem, sal deur die swaard verteer word. ${ }^{15}$ Moulder was van me- 
ning dat Christus nie elke vorm van geweld verwerp het nie en baseer sy siening op Joh. 2:13-17, toe Jesus 'n sweep van toutjies gevleg het en almal wat handel gedryf het, uit die tempel verjaag het. ${ }^{16}$ Die apostels Paulus en Petrus, verkeer dikwels saam met die soldate en het nie by een geleentheid hulle afgewys of vyandig teenoor hulle gestaan nie. ${ }^{17}$ Paulus het ook nie die dra van wapens verbied nie, trouens, hy vergelyk die Christen met 'n soldaat. ${ }^{18}$

\section{Vroeë Christelike Kerk}

Met die begin van die vroeë Christelike Kerkgeskiedenis begin 'n tydvak wat eeue lank konflikte sou meebring, omdat lede van die kerk, ook dié wat soldate was, anders as vroeër, nou in die wêreld gestaan het, maar nie meer van die wêreld was nie. Vanweë hul Christenskap, kon hulle nie meer meedoen aan alles wat in die samelewing aangegaan het nie. Daar het onderskeid tussen die lede van die Kerk en ander nieChristelike burgers van die Romeinse Ryk gekom. Die Christene het nie vyandig teenoor die staat as sodanig gestaan nie, maar daar was 'n aantal basiese beginsels op grond waarvan hulle radikaal met die heidense staat verskil het. Geen Christen kon as gevolg van sy geloofsoortuiging aan enige keiserverering deel hê nie, en geen Christen sou aan die Romeinse gode offer nie. Geweld, bloedvergieting en oorlogvoering kan nooit deel word van 'n Christen se bestaan nie. ${ }^{19}$ Dit sou moeilik vir 'n Christen-soldaat wees om sy geloof uit te leef, omdat van soldate, veral die in offisiersgeledere, soms verwag is om doodsvonnisse op te lê, en van gewone soldate om dit te voltrek. Alle soldate moes die eed van getrouheid aan die keiser aflê, 'n verpligting wat deur die Kerk as keiserverering beskou is. Die Romeinse Leër het aan baie heidense gebruike deelgeneem soos offers wat gebring is aan die Romeinse gode. Getrouheid aan die leër het dus dikwels martelaarskap tot gevolg gehad.

Tog is daar getuies dat daar ' $n$ hele aantal Christene onder die soldategeledere was. Tydens die regering van Marcus Aurelius $( \pm 173$ ) dien daar ook 'n aantal soldate wat Christene was. Aurelius meld dit in 'n brief aan die Senaat dat hy met sy soldate na 'n veldslag op pad was. Dit was baie droog en die soldate was dors, maar hulle kon geen water vind nie. Christensoldate wat onder hulle was, het saamgekom om om reën te bid. Kort daarna het dit gereën. Hierdie soldate was waarskynlik soldate wat tot die Christelike godsdiens bekeer is, en nie Christene wat vrywillig as soldate aangesluit het nie. ${ }^{20}$ Die
Christelike Kerk het dus nie van 'n soldaat verwag om uit die leër te bedank wanneer hy tot bekering kom nie.

In die derde eeu word ook 'n hele aantal Christen-soldate in die leërs opgemerk. Die evangelie is oral en te alle tye verkondig, ook onder die soldategeledere. ${ }^{21}$

Christene was nie sonder meer teen militêre diensplig gekant nie. Daar is 'n onderskeid gemaak tussen 'militare' en 'bellare'. Met 'militare' is 'n persoon aangedui wat aan die leermag behoort het, terwyl 'bellare' iemand aangedui het wat aktief aan die stryd deelgeneem het. ${ }^{22}$ Clemens (216) stel die plek van die Christen in vredestyd en oorlog soos volg: 'We are being educated, not in war, but peace' en voeg hieraan toe dat 'n soldaat wat 'n Christen geword het, soldaat mag bly, maar dat 'n Christen hom nie in krygsdiens mag begewe nie. ${ }^{23}$

\section{Konstantyn die Grote}

Gedurende die tyd van Konstantyn die Grote het 'n groot verandering plaasgevind. Die sogenaamde 'Goue Eeu' het aangebreek, omdat Kerk en Staat met mekaar versoen geraak het. Tydens Konstantyn die Grote se opmars teen Maxentius het hy ' $n$ visioen gehad waarin die Christusmonogram as oorwinningsteken gegee is. Hierdie embleem is op sy skilde en veldtekens aangebring. Saam met die oorwinningsteken is die woorde (in) hoc (signo) vince (s) (in hierdie teken oorwinning) as opdrag aan hom gegee. ${ }^{24}$ Sodoende het Konstantyn die eerste Christenkeiser geword en is godsdiensvryheid deur die edik van Milaan in 313 n.C. afgekondig. Die Kerk se siening t.o.v. militêre diensplig het verander en talle Christene het by die leërs aangesluit. In 'n Christelike staat waar alle heidense gebruike afgeskaf is, het dit vir 'n Christen makliker geword om 'n soldaat te word aangesien oorlog 'n manier geword het om die Christendom na heidense lande uit te brei.

Konstantyn het 'n draagbare kapel (capella) laat oprig en het godsdiensoefeninge te velde vir sy soldate laat hou. Hy stel Kapelane (capellanus) aan en bevorder godsdiens onder die soldategeledere. Augustinus (354-430) dring daarop aan dat oorlogvoering regverdig moet wees en dat juis dit die maatstaf moet wees waaraan oorlogvoering getoets moet word. 'n Oorlog moet regverdig in sy oorsake, voortsetting, uitvoering en doelstellings wees. Daar kan egter nie 'n regverdige oorlog wees, sonder dat daar 
'n onregverdige oorlog deur die vyand gevoer word nie, want in liefde kan mense mekaar tog nie doodmaak nie. 'n Aanval van een nasie op 'n ander, is dieselfde as ' $n$ misdaad, dieselfde as moord en diefstal, en dit moet teengestaan word. Oorlog word gevoer om vrede te bewerkstellig. ${ }^{25}$

\section{Ambrosius}

Ambrosius (340-397) keur oorlogvoering en militêre diensplig ook goed as dit op 'n regverdige grondslag plaasvind. ${ }^{26}$ Die edik van Keiser Theodosius II het bepaal dat alleen Christene tot sy leërs toegelaat word. ${ }^{27}$ Interessant om daarop te let dat die voorwaarde vir die toelating tot 'n leër, Christenskap word.

Augustinus en Ambrosius aanvaar die noodsaaklikheid van oorlog onder sekere omstandighede. 'n Christelike staat moet oor 'n weermag beskik. Hulle grond hul sienswyse op Rom. 13:4b: 'Maar as jy kwaad doen, vrees dan; want hy dra die swaard nie verniet nie, want hy is 'n dienaar van God, 'n wreker om die een wat kwaad doen te straf'. ${ }^{28}$ Die owerheid dra dus die swaard van God

\section{Kruistogte}

Die Kruistogte (1096-1291) ontstaan onder beskerming van die Kerk of geïnspireer deur 'n godsdienstige leier. Die Kerk roep die volk op tot ' $n$ heilige oorlog teen die Islam. Hierdie oorloë is nie gevoer ter wille van reg en geregtigheid of om lewe en eiendom te beskerm nie, maar dit was die navolging van 'n ideaal; om die Turkse beheer (Islam) oor Christelike gebiede te vernietig. Die geestelikes neem self die wapen op in die heilige oorlog. Die pous het elke kruistog gemagtig en selfs bepleit.

\section{Monnikordes}

'n Belangrike uitvloeisel van die Kruistogte is die ontstaan van die militêre monnikordes. Die lede van hierdie monnikordes het dit as hul roeping beskou om soldate van Christus te wees. Daar word die Tempelridders (Tempeliers), die Duitse Ridders, die Ridders van die Swaard en die Hospitaalridders (Johanniters) aangetref. ${ }^{29}$

Hierdie godsdienstige militêre ordes het uit drie groepe bestaan, t.w. die ridders (vegtendes), die diensdoenende broeders (wat siekes versorg, administrasie behartig en vir die huishouding verantwoordelik was) en die kapelane (wat die geestelike bearbeiding behartig het). Die kapelane het die ridders te velde vergesel om godsdiensoefeninge vir hulle waar te neem. Die kapelaanskorpse, wat afgesonder is om geestelike bearbeiding van ridders te behartig, het hulle ontstaan aan die ridderordes te danke. ${ }^{30}$

Die orde van die Johanniterridders, ook die Malteserridders genoem, het sy ontstaan gedurende die Eerste Kruistog (1099) gehad. Die orde bestaan vandag nog in verskillende lande, en die lede lê hulle toe op die verpleging van siekes en bewys liefdadigheid aan mense. In die midde van hierdie orde, is die eerste tekens van georganiseerde kapelaanskorpse teëgekom. Die lede van die Johanniter-orde het die Johanniter- (Maltese) kruis as kenteken gedra. Hierdie agtpuntige kruis het ook die kenteken van 'n aantal kapelaanskorpse, onder andere die kapelaanskorps van die Suid-Afrikaanse Weermag geword. ${ }^{31}$

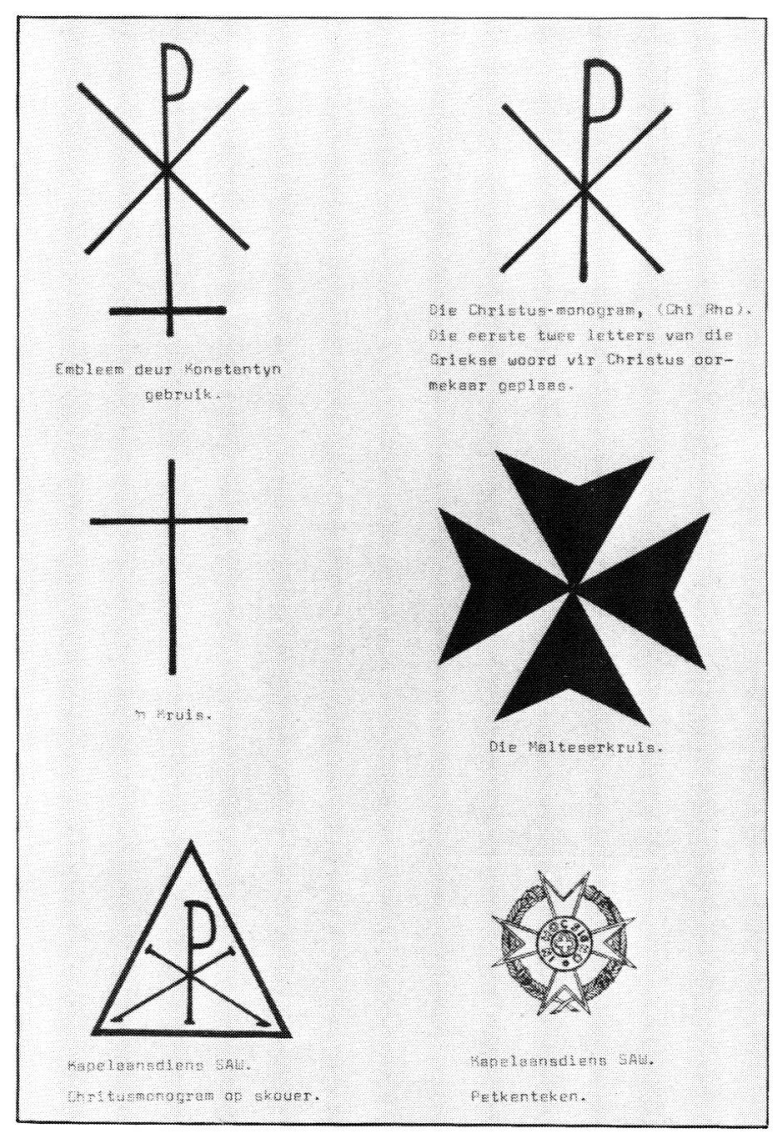

Embleme en kentekens van onderskeidelik Konstantyn die Grote, die Malteserridders en Kapelaansdiens van die SAW.

\section{Frans - Engelse Oorloë}

In die Frans-Engelse Oorloë en die EngelsSkotse Oorloë gedurende die twaalfde tot die vyftiende eeu, neem die geestelikes nog steeds ' $n$ belangrike aandeel in die oorlogvoering van 
die betrokke lande. Militêre diensplig word as godgegewe taak en roeping gesien. ${ }^{32}$

\section{Zwingli}

Huldreich Zwingli (1484-1531) het as kapelaan saam met sy land se troepe na die front vertrek. Saam met hulle maak hy oorwinnings en neerlae mee. Zwingli het oorlogvoering, wat in diens van die vaderland of Evangelie gevoer word, goedgekeur. ${ }^{33}$

\section{Luther}

Martin Luther (1483-1546) verwerp offensiewe oorlog, maar is ten gunste van deffensiewe oorlog. Hy is van mening dat die staat slegs kan bestaan met die hulp van ' $n$ weermag, en 'n weermag impliseer dadelik die moontlikheid van oorlog ${ }^{34}$ ' $n$ Burger van ' $n$ land moet militêre diens vir sy land lewer wanneer die staat dit verlang en wanneer dit op regverdige grondslag berus. Volgens hom is diens aan die staat gelewer, gelykstaande aan diens aan God. ${ }^{35}$

\section{Calvyn}

Johannes Calvyn (1509-1564) verwerp enige vorm van opstand maar aanvaar oorlog. Vir hom is daar geen verskil wanneer die staat ' $n$ persoon straf of teen ' $n$ ander land optree nie. Hy stel dit duidelik dat die Nuwe Testament nie bedoel is as handboek wat riglyne neerlê vir burgerlike owerhede nie, maar wel vir die verkondiging van die koninkryk van Christus. Hy wys ook daarop dat Christus self niks aan die omstandighede verander het nie. Vir owerhede moet oorlog die laaste uitweg wees. ${ }^{36}$

\section{Bullinger}

Bullinger (1504-1575) wys daarop dat die Here dikwels die soldate gebruik om die Kerk te beskerm. So het soldate Paulus beskerm toe hy voor Keiser Felix moes verskyn. ${ }^{37}$

\section{Tydperk na Hervorming}

In die eeue na Hervorming was dit gebruik om geestelikes af te sonder om godsdiensoefeninge vir die soldate en matrose waar te neem. Nederland het die gebruik gehad om saam met elke skip 'n geestelike, genoem 'n sieketrooster, te stuur. ${ }^{38}$

Behalwe vir die eerste drie eeue waarin die Kerk deur die heidense staat vervolg is, is dit duidelik dat die Christelike Kerk militêre diensplig as 'n godgegewe taak en roeping aanvaar het. ${ }^{39}$

\section{Suid-Afrika}

In Suid-Afrika was krygsdiens en godsdiens nou verbonde aan mekaar. Godsdienstig en geskiedkundig beskou, het die huidige amp van geestelike versorgers in die Suid-Afrikaanse Weermag voortgespruit uit die behoefte van die gelowiges om, waar hulle tydelik of blywend op eie bodem of in die vreemde, in gevestigde omstandighede of op die pad geplaas was, steeds van geestelike bystand verseker te wees. ${ }^{40}$

\section{Bartholomeus Dias}

Bartholomeus Dias, ontdekker van die Kaap die Goeie Hoop, het in 1488 by Angra Pequena 'n kruis opgerig as teken dat dié deel van SuiderAfrika deur die Christendom in besit geneem is. Aan boord van sy skepe was daar ook 'n priester wat in Algoabaai die heilige Nagmaal aan die matrose bedien het. ${ }^{41}$

\section{Vasco da Gama}

In 1497 het Vasco da Gama die Kaap omseil en in Mosselbaai 'n suil met 'n marmerkruis opgerig. Aan boord was daar twee Trinitariër-monnike. Op sy tweede reis het hy twee sendelinge van die Fransiskaanse Orde saamgeneem. ${ }^{42}$

Aan boord van die Nederlandse ontdekkings- en handelsendings was geestelike versorgers aanwesig om aan opvarendes geestelike bystand te verleen. Die eerste sieketroosters wat saam met die skepe onder Van Neck en Warwijk (1598) vertrek het, was Philippus Pieterzoon en Jacob Mattheus. ${ }^{43}$

In die bykans twee eeue van sy bestaan, het die V.O.C. ruim 900 predikante en enige duisende sieketroosters, op eie koste, saam met die skepe na handels- en bestuursposte uitgestuur. ${ }^{44}$

\section{Jan van Riebeeck}

Met die aankoms van Van Riebeeck in Tafelbaai op 6 April 1652, breek die geboortedag van die Suid-Afrikaanse volk aan. Saam met Jan van Riebeeck sit Willem Barentsz Wylant, die eerste sieketrooster, voet aan wal. Wylant is verantwoordelik vir die godsdiensoefeninge en geestelike bearbeiding van soldate, matrose en amptenare aan die Kaap. Die eerste besoekende le- 
raar is ds. Johannes Backerus wat op die skip 'Oliphant' op 10 Mei 1652 die Kaap aandoen. ${ }^{45}$

In 1665 het daar reeds vier sieketroosters aan die Kaap gearbei en drie en dertig predikante die Kaap besoek. Onder die lidmate wat deur hierdie sieketroosters bearbei is, was daar 'n hele aantal soldate en matrose. In die notules van die kerkrade kom mens telkens op name van soldate af wat in die kerklike lewe betrek is en self in die kerkrade gedien het. In die notule van die Kaapse gemeente kom o.a. die name voor van sersant Isaac Victor (1686) wat as diaken gedien het en luitenant Adriaan van Rheede (1692) wat as ouderling gedien het. ${ }^{46}$

\section{Britse Besetting}

Op 16 September 1795 is die Kaap deur die Britse owerheid oorgeneem en het die Nederlandse gesag voorlopig geëindig. Saam met die Britse troepe het die eerste Anglikaanse militêre kapelaan, vlootkapelaan J.E. Attwood, aan die Kaap aangekom. Hy is afgesonder om die militêre aan die Kaap geestelik te versorg. Gedurende die eerste Britse besetting (1795-1803), het vyf Anglikaanse Kapelane onder die Britse soldate en matrose gearbei. ${ }^{47}$

\section{Bataafse Tydperk}

Met die vrede van Amiens, op 27 Maart 1802 is die Kaap aan die Bataafse Republiek toegeken. Tydens die kort bestuurstyd van die Bataafse Republiek (1803-1806) het die soldate nog steeds hulle plek in die kerklike lewe volgestaan en is die militêre as lede van die plaaslike gemeentes bearbei. 48

\section{Tweede Britse Besetting}

Op 10 Januarie 1806 word die Kaap amptelik deur die Britse mag onder genl Baird in besit geneem. Na die tweede Britse besetting het die aantal kerkgenootskappe uitgebrei. Dit is gedurende hierdie tydperk dat daar op Suid-Afrikaanse bodem militêre kapelane afgesonder is om uitsluitend die militêre te versorg. ${ }^{49}$ Met die Sesde Grensoorlog (1834-1835) aan die Kaap, het militêre kapelane met die Britse troepe saamgegaan om godsdiensoefeninge te hou. Gedurende hierdie oorlog het die plaaslike Wesleyaanse sendelinge ook dienste vir die troepe te velde gehou, onder meer te Butterworth. In Grahamstad is 'n diens vir die soldate deur die 'acting District Chaplain' in die Anglikaanse Kerk 'St. Georges' gehou. ${ }^{50}$
Teen die einde van 1848 word die militêre kapelane na Kaffraria en Natal gestuur. In 1852 word daar kapelane met die Britse troepe te velde by die Amatolaberge in die Oostelike Provinsie aangetref. ${ }^{51}$ Die kerkhistorikus Whiteside meld dat Britse soldate ' $n$ belangrike rol gespeel het in die totstandkoming van Metodistegemeentes in Suid-Afrika. ${ }^{52}$

\section{Die Groot Trek}

Met die Groot Trek (1836) het die trekkers die Kaapkolonie verlaat om die juk van die Britse Ryk van hulle af te skud, maar ook met die vaste voorneme om hulle godsdiens te behou. Die Engelse inwoners van Grahamstad het ' $n$ Bybel aan die Voortrekkers gegee om saam te neem. ${ }^{53}$ Die Voortrekkers het uit die staanspoor alles in hulle vermoë gedoen om leraars te vind om saam met hulle te gaan ${ }^{54}$ Die Amerikaanse sendeling eerw. Daniël Lindley het die Voortrekkers in hulle geestelike nood tegemoetgekom. Vanaf 1840 tot 1847 het hy hom aan die geestelike bearbeiding van die Voortrekkers gewy. ${ }^{55}$

By Bloedrivier het die Voortrekkers voor die aangesig van die dood gestaan. Elf dae voor die slag gelewer is, het Andries Pretorius al sy offisiere bymekaar geroep en hulle herinner 'hoe ene zaak zonder God begonnen, verijdeld wordt; hoe een ieder zich behoorde te gedragen, in het slaan tegen den vijand; dat wij, als redelijke schepsels, onder het licht van het Evangelie geboren het niet gelijk moeten zijn, in het vernielen van onnoozele vrouwen en zuigelingen; en dat wij van God begeren mogen, hetgeen met Zijne gestrenge rechtvaardigheid nie strijdig is'. Op Sondag 9 Desember is die gelofte die eerste keer afgelê. Sarel Cilliers het daarin voorgegaan, in die tent van generaal Andries Pretorius. ${ }^{56}$ Die gelofte het gelui dat as God hulle die oorwinning skenk, sou hulle en hulle nageslag die dag as 'n Sondag herdenk, en sou hulle 'n kerkgebou oprig tot eer van Sy naam. Die oorwinning is behaal en die Voortrekkers het hulle gelofte nagekom. Bloedrivier was nie net 'n oorwinning vir die Voortrekkers en die Afrikanerdom nie, maar ook vir die beskawing in die algemeen.

\section{Die tydperk 1865-1899}

Gedurende die tydperk (1865-1899) was daar verskeie geleenthede waar die burgers die wapens moes opneem. In hierdie tyd sou die amp van die kapelaan, $\mathrm{nl}$. 'n afgesonderde leraar wat die geestelike versorging van die burgers te 
velde behartig, weer sterk na vore kom. Tydens die ekspedisie teen die Basoeto's in 1865 het die President van die Oranje-Vrystaat self voorsiening vir die geestelike versorging van die manne te velde gemaak. Ds. Gilles van de Wall van Bloemfontein en ds. Pieter Roux van Smithfield het as kapelane by die burgers gedurende die Basoeto-oorlog aangesluit. In 1876 met die oorlog teen Sekoekoeni, neem staatspresident Thomas Francois Burgers, wat tot 1872 predikant op Hanover was, self die godsdiensoefeninge te velde waar. ${ }^{57}$

\section{Basoeto-oorlog}

Tydens die Basoeto-oorlog van 1880-1881 het die Kaapse sinode twee leraars as geestelike versorgers saam met die burgers gestuur. Dit was ' $n$ amptelike uitstuur van kapelane deur die Kerk om die burgers onder die wapen geestelik te versterk.

\section{Eerste Vryheidsoorlog}

Tydens die Eerste Vryheidsoorlog (1880-1881) het die Transvaalse leraars die burgers wat vir hul staatkundige vryheid en onafhanklikheid die wapen opgeneem het, geestelik gesterk en gelaaf. In die werk van J.P. Weilbach word daar verskeie kere van die godsdiensoefeninge te veld, melding gemaak. So noem hy bv. aangaande die inrigting van 'n versamelplek die volgende: 'Daar was een tent of kerk gebouwd met bokwagenzeilen' ${ }^{58}$

\section{Tweede Vryheidsoorlog}

Tydens die Tweede Vryheidsoorlog (18891902) het die Kommandoprediker weer sterk op die voorgrond getree. Die behoorlike toerusting van ' $n$ kommando, het die behartiging van geestelike versorging, ingesluit. Daar was 156 kommandopredikers saam met die burgers van hulle omgewing in die stryd betrokke. Hulle het saam ontberings en gevare getrotseer, te velde en in krygsgevangene- en konsentrasiekampe, in hul eie land of in die vreemde. In hul geledere was ds. Pieter Roux wat die rang van generaal beklee het. Wat die geestelike bearbeiding te velde betref, het die leraars nie hul gemeentes 'verlaat nie, maar wel met hul gemeentes 'saamgegaan'. Daar kan dus eerder van swerwende gemeentes gepraat word. In die Transvaal en Vrystaat was daar sowat 82000 burgers onder die wapen. Benewens Evangeliedienaars wat vir die geestelike versorging verantwoordelik was, was daar ook kerkraadslede en lidmate wat met gods- diensoefeninge opgetree het, waar daar nie veldpredikers teenwoordig was nie. Dit was ook algemene gebruik dat die generaals met godsdiensoefening voorgegaan het.

Daar is sowat 31000 mans en jeugdiges in krygsgevangenekampe weggevoer, terwyl sowat 73 geestelike werkers in die kampe gearbei het. In die binnelandse kampe het die leraars godsdiensoefeninge gehou, katkisasie waargeneem en die geestelike bearbeiding van die geïnterneerdes behartig. Buite die grense van Suid-Afrika is burgers in Portugal, St. Helena, Bermuda, Ceylon en Indië geïnterneer. In meeste van die kampe is predikante afgesonder om die geïnterneerdes te bearbei. Die krygsgevangenes, en hul gemeentes het alles in hulle vermoë gedoen om die kerklike werksaamhede die normale gang te laat gaan. Daar is selfs in Indië, met sendingwerk onder die inheemse bevolking begin.

\section{Eerste Wêreldoorlog}

Gedurende die Eerste Wêreldoorlog (19141918) het dit geblyk dat plaaslike leraars betrek is om met die geestelike bearbeiding behulpsaam te wees. Hierdie gebruik is in die kamp op Booysens, Johannesburg, gehandhaaf. Die leraars wat hierdie werksaamhede verrig het, het nie oor 'n amptelike aanstelling as deeltydse kapelane, beskik nie, terwyl daar ook geen vaste kapelane deel van die Univerdedigingsmag uitgemaak het nie. Op 13 Augustus 1914 is die eerste aanstelling van deeltydse kapelane gemaak. Later is op aanbeveling van genl J.C. Smuts, die destydse minister van verdediging, vier voltydse kapelane aangestel. Verdere aanstellings volg later. Aanvanklik is kapelane met die rang van kaptein aangestel en is daar van 'Veldprediker Kaptein' gepraat. In Augustus 1915 het daar 43 kapelane diens gedoen, hoofsaaklik in die Unie en Duits-SuidwesAfrika. Wanneer die Imperiale magte ook na Duits-Oos-Afrika en Sentraal-Afrika trek, word 'n hele aantal kapelane saam met die troepe gestuur. Kapelane van die Unieverdedigingsmag het ook in Europa diens gedoen. Nie alleen leraars van die Protestante geloof het gedien nie, daar was ook twee Joodse rabbi's. Twee sendelinge het onder die nie-blankes gearbei.

\section{Tweede Wêreldoorlog}

Die geestelike versorgers tydens die Tweede Wêreldoorlog (1939-1945) was te alle tye by die troepe, in militêre kampe, by militêre basisse, in die hospitaal, op see en in die voorste linies. 


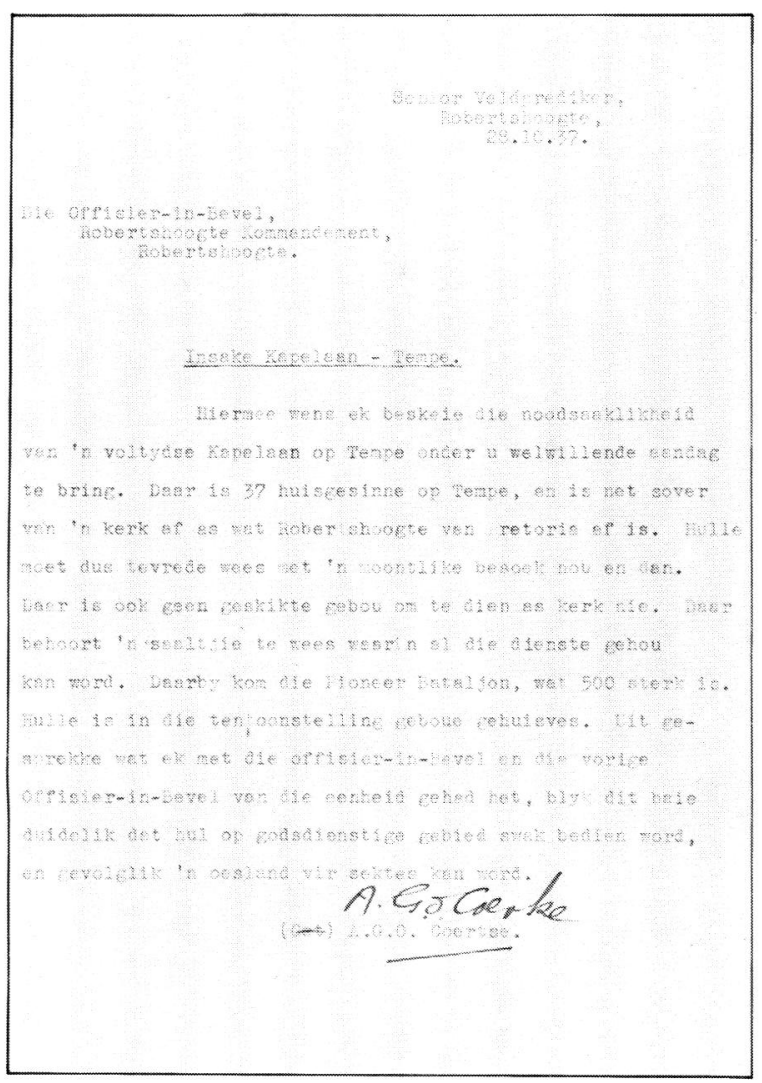

'n Pleidooi deur die senior Veldprediker van Robertshoogte vir 'n voltydse kapelaan te Tempe.

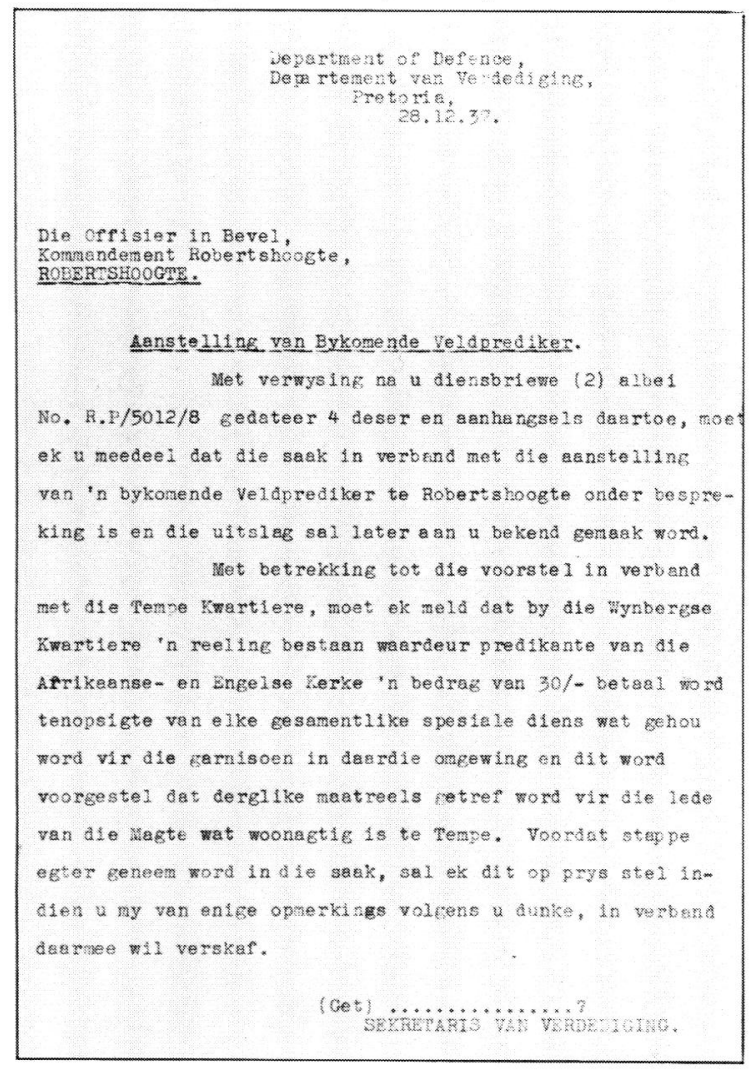

'n Afskrif van 'n brief waarin gemeld word dat die aanbeveling om 'n bykomende veldprediker te Robertshoogte aan te stel, aandag geniet. 'n Aanbeveling word gemaak dat dieselfde reëlings getref word by Tempe as wat in gebruik is by Wynberg.
Daar het ongeveer 517 blanke en 38 nie-blanke kapelane onder sowat 350369 soldate gedurende die Tweede Wêreldoorlog gearbei. Onder die name van die troepe aan wie dekorasies en medaljes gedurende die Tweede Wêreldoorlog toegeken is, kom daar ' $n$ hele aantal kapelane voor.

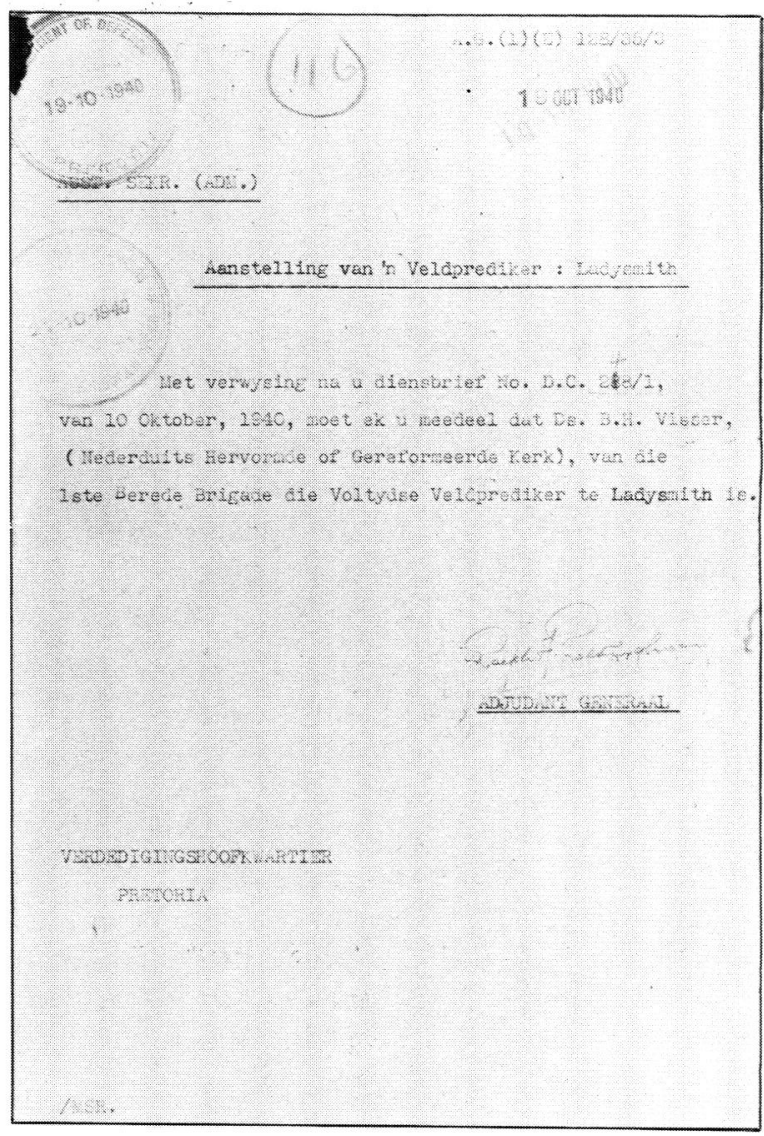

'n Aanstellingsbrief van ds. B.H. Visser as voltydse Veldprediker van die eerste Berede Brigade te Ladysmith, 19 Oktober 1940.

\section{Korea}

In Augustus 1950 is ds. M.D.V. Cloete na Korea gestuur om geestelike bearbeiding van die SuidAfrikaanse troepe aldaar te behartig. Altesaam vier kapelane het mekaar in Korea opgevolg.

Die geestelike het dus in die Suid-Afrikaanse militêre geskiedenis ' $n$ belangrike rol gespeel. Op 1 Oktober 1946 is die S.A. Kapelaanskorps as eenheid van die Weermag gestig. In 1965 is die eerste kapelaan bevorder tot die rang van kolonel. Die groei van die SAW het die behoefte aan meer kapelane laat ontstaan. Die benaming 'Veldprediker' verander na 'Kapelaan'. In 1968 het die Kapelaanskorps 'n onafhanklike direktoraat geword onder die Hoof van die SAW Administrasie. Die direkteur het die rang van brigadier beklee. In 1970 is die benaming Direkteur van Kapelane verander na Kapelaan-Generaal van 
die SAW. Op 1 April 1973 is die Kapelaanskorps na 'n outonome eenheid van die SAW verander, met ' $n$ eie hoofkwartier. Die Kapelaansdiens is die medium waardeur die Kerk aan die godsdienstige behoeftes van Weermagslede voldoen. Die SAW maak voorsiening vir 30 verskillende denominasies. Tans is daar 108 Staandemagkapelane. In 1983 het 128 Nasionale Dienspligtiges as kapelane diens gedoen en vanjaar is daar 107 dienspligkapelane in die SAW. In 'n geval waar minder as 200 lidmate 'n denominasie verteenwoordig in 'n gebied of eenheid, maak die SAW van 'n deeltydse Kapelaan gebruik wat per uur vergoed word vir sy diens. ${ }^{59}$

* Lt A. Boshoff, BA Hons THOD, is verbonde aan die Militêre Informasieburo van die SAW.

\section{Bibliografie}

1. Buys, P.W., The Christian and War, PU vir CHO 1977, p. 1.

2. Ibid, p. 11

3. Ibid.

4. Deut. 20.

5. Buys, op. cit. p. 12

6. Ibid.

7. In hierdie teken nr. 1, Die Christen in Univorm, SAW Kapelaansliteratuurkommissie, p. 4.

8. Luk. $3: 4$

9. Luk. $7: 1-10$.

10. Matt. 27.

11. Luk. 23:34.

12. Matt. $22: 21$

13. Luk. $14: 31-33$.

14. Matt. 5:38-48.

15. Matt. $26: 47-56$

16. Pacifism and Conscientious Objection nr. 34, Literature Commission of the SADF Chaplains' Service, p. 4.
17. Hand. 27 en 28.

18. Ef. $6: 11-17$.

19. In hierdie teken op. cit. p. 6 .

20. Ibid.

21. Ibid, p. 7.

22. Ibid.

23. Ibid.

24. Potgieter, J.F., Die Militêre Kapelaan, Doktorale Proefskrif, Universiteit van Pretoria, 1971, p. 47.

25. Ibid.

26. Ibid.

27. Ibid.

28. Buys, op. cit., p. 2.

29. Potgieter, op. cit., pp. 71 en 72.

30. Ibid.

31. Ibid.

32. In hierdie teken, op. cit., p. 10.

33. Ibid.

34. Buys, op. cit., p. 3.

35. In hierdie teken, op. cit., p. 11

36. Buys, op. cit., p. 4

37. In hierdie teken, op. cit., p. 11

38. Ibid., p. 12.

39. Ibid.

40. Potgieter, op. cit. p. 101.

41. Ibid.

42. Ibid.

43. Ibid, p. 102

44. Ibid, p. 105.

45. Ibid, p.108.

46. Ibid, p. 109

47. Ibid, p. 115.

48. Ibid, p. 117

49. Ibid, p. 119

50. Ibid, p. 123.

51. Ibid, p. 124.

52. Ibid, p. 126

53. Ibid, p. 142.

54. Ibid, p. 143.

55. Ibid.

56. Gedenkuitgawe die Huisgenoot, Desember 1938, p. 127.

57. Potgieter, op. cit., p. 144.

58. Ibid, p. 145.

59. Kapelaan-Generaal. 